DOI https://doi.org/10.30525/978-9934-26-114-5-12

\title{
ОСОБЛИВОСТІ ПОВЕДІНКИ ТА ЕМОЦІЙНО-ОСОБИСТІСНОЇ СФЕРИ ЕМОЦІЙНО ДЕПРИВОВАНИХ ДІТЕЙ МОЛОДШОГО ШКІЛЬНОГО ВІКУ
}

\author{
Цумарєва Н. В. \\ старший викладач кафедри психологї та педагогіки \\ Кропивнищький інститут Приватного вищого навчального закладу \\ «Університет сучасних знань» \\ м. Кропивницький, Украӥна
}

Багаточисельними дослідженнями в області педагогіки, соціології, психології та психіатрії доведений визначальний вплив періоду дитинства на все подальше життя людини. Особливого значення при цьому набувають фактори середовища, в якому перебувають діти, соціально-психологічний мікроклімат групи, внутрішні та зовнішні ресурси, які визначають можливості для розвитку, та психологічні травми дитинства. Найбільш вразливу групу у цьому відношенні становлять діти-сироти, діти, позбавлені батьківської опіки та діти, які виховуються в неблагополучних сім'ях, оскільки дефіцит близьких емоційних відносин зі значимим дорослим (батьками, або особами, які їх замінюють) призводить до раннього деприваційного досвіду таких дітей, а також вилучення їх із неблагополучних сімей і влаштування під опіку держави $[3 ; 4 ; 6]$.

Не зважаючи на зростання поширеності сімейних форм влаштування дітей-сиріт, мільйони дітей по всьому світу так і продовжують проживати та виховуватись в умовах інституціональних закладів. Загальновизнаним є той факт, що інтернати не можуть забезпечити оптимальні умови для повноцінного психічного розвитку дітей. Окрім того, жорстоке поводження, емоційне насилля, зневажливе ставлення, емоційна знехтуваність, байдужість та нездатність біологічних батьків належним чином піклуватися про своїх дітей, призводить до виникнення емоційної депривації, що часто корелює 3 проблемами психічного розвитку та здоров'я, які діагностуються у таких дітей згодом при переміщенні їх в інтернати чи прийомні сім'ї.

Під емоційною депривацією ми розуміємо «процес довготривалого перебування особистості в умовах емоційно збідненого середовища, що спричиняється незадоволенням емоційних потреб та відсутністю можливостей для встановлення емоційних зв'язків, контактів 
зі значимою особою, що спричиняє дисфункцію, порушення та розлади психофізичної та психосоціальної сфери особистості» [1, с. 67].

Також у дітей, які довготривалий час знаходилися під впливом емоційної депривації відмічається виникнення внутрішньої та зовнішньої психопатології у всіх вікових періодах. Так, виявлено, що рання емоційна депривація призводить до порушень в когнітивній сфері, труднощів саморегуляції, емоційної лабільності, та виникнення депресії [5].

У емоційно депривованих прийомних дітей спостерігаються серйозні емоційні та поведінкові проблеми на відміну від звичайних дітей. Так, для прийомних дітей характерні низький рівень соціального та емоційного інтелекту, агресивна та делінквентна поведінка, труднощі у взаєминах з однолітками. Причому збільшення рівня поведінкових проблем корелює із віком дітей на момент усиновлення. Також відмічаються факти повернення дітей із заміщуючих сімей назад в інтернатні заклади, коли прийомні батьки виявляють нездатність впоратися 3 цілим рядом психологічних та поведінкових проблем таких дітей [2].

Необхідно відмітити, що вплив деприваційного досвіду, пережитого в дитинстві може мати відстрочені наслідки. Так, порушення функції осі гіпоталамус-гіпофіз-наднирники та підвищення рівня кортизолу зберігається тривалий час у дітей навіть після успішного усиновлення i проживання в умовах благополучного сімейного середовища [7].

Для виявлення особливості поведінки та емоційно-особистісної сфери емоційно депривованих дітей, нами було проведено емпіричне дослідження. Вибірку склали 180 дітей молодшого шкільного віку, об'єднаних у три групи: діти-сироти, прийомні діти та діти з біологічних сімей. Психодіагностичним інструментарієм для дослідження став комплекс валідних та взаємодоповнюючих методик: Шкала кольорового діапазону настрою Лутошкіна, Тест-опитувальник емпатичних тенденцій Меграбіена, Тест фрустрації Розенцвейга, Шкільний тест тривожності Філліпса, Карта спостережень Стотта, Оціночна шкала емоційних проявів дитини Шванцара та проєктивна методика «Будинок-дерево-людина» Бука.

Проведене нами психодіагностичне дослідження дало змогу констатувати, що дітям із високим рівнем емоційної депривації характерні певні особливості поведінки та емоційно-особистісної сфери, на відміну від дітей молодшого шкільного віку, які не зазнали впливу емоційної депривації. Так, профіль емоційно депривованих молодших школярів характеризується дазадаптивною поведінкою, складністю процесу адаптації до змінних умов середовища, високим рівнем недовіри до незнайомих людей, низький рівень довільності поведінки, 52 
демонстрацією агресивності та екстрапунітивності в ситуаціях фрустрації, конфліктність у міжособистісній взаємодії, психологічний протест на вимоги дорослих. Також у дітей з емоційною депривацією відмічається неконтрольованість афектів, алекситимія, підвищений рівень вразливості та образливості, капризність, ревнивість, страхи та ворожість у відносинах із малознайомими однолітками та дорослими, невідповідність емоційних реакцій життєвим ситуаціям, неадекватність самооцінки, низький рівень самостійності.

Таким чином, ми бачимо, що довготривале перебування дітей молодшого шкільного віку в ситуації емоційної депривації призводить до виникнення особливих форм поведінки та емоційно-особистісної сфери, які негативно впливають на особистісний розвиток та потребують раннього виявлення та корекції.

\section{Література:}

1. Цумарєва Н.В. Теоретико-емпіричне дослідження феномену емоційної депривації. Науковий вісник Миколаївського національного університету імені В. О. Сухомлинського. Психологічні науки : збірник наукових праць. Миколаїв : МНУ імені В. О. Сухомлинського, 2021. № 2 (21). C. 62-69.

2. Baars C.W., Terruwe A.A., Baars S.M., Shayne B.N. Healing the Unaffirmed: Recognizing Emotional Deprivation. N.Y.: Alba House; Revised, Updated edition, 2020. $221 \mathrm{p}$.

3. Hostinar C.E., Stellern S.A., Schaefer C., Carlson S.M., Gunnar M.R. Associations between early life adversity and executive function in children adopted internationally from orphanages. Proceedings of the National Academy of Sciences, 2012, № 109. P. 17208-17212. DOI: https://doi.org/10.1073/pnas.1121246109

4. Kennedy M., Kreppner J., Knights N., Kumsta R., Maughan B., Golm D., Rutter M., Schlotz W., Sonuga-Barke E.J. Early severe institutional deprivation is associated with a persistent variant of adult attentiondeficit/hyperactivity disorder: clinical presentation, developmental continuities and life circumstances in the English and Romanian Adoptees study. J Child Psychol Psychiatry, 2016. № 57(10). P.1113-1125. DOI: https://doi.org/10.1111/jcpp.12576

5. Kumsta R., Schlotz W., Golm D., Moser D., Kennedy M., Knights N., Kreppner J., Maughan B., Rutter M., Sonuga-Barke E. HPA axis dysregulation in adult adoptees twenty years after severe institutional deprivation in childhood. Psychoneuroendocrinology, 2017. № 86. P. 196202. DOI: https://doi.org/10.1016/j.psyneuen.2017.09.021 
6. Merz E.C., McCall R.B. Behavior problems in children adopted from psychosocially depriving institutions. Journal of Abnormal Child Psychology, 2010. № 38. P. 459-470. DOI: https://doi.org/10.1007/s10802009-9383-4

7. Miller A.B., Machlin L., McLaughlin K.A., \& Sheridan M.A. Deprivation and psychopathology in the Fragile Families Study: A 15-year longitudinal investigation. Journal of Child Psychology and Psychiatry, 2020. № 62. P. 382-391. DOI: https://doi.org/10.1111/jcpp.13260 